\title{
The Performance Of English Speaking Skill Used By The Receptionist Of Purna Wisata Tour And Travel
}

\author{
Sitti Halijah ${ }^{1}$, Dewi Bastian ${ }^{2}$ \\ ${ }^{1,2}$ Sastra Inggris, Fakultas Sastra, Universitas Muslim Indonesia \\ sittihalijahlekki@gmail.com
}

\begin{abstract}
The reseach objectives are to know whats ymbols are performed in Lariangi dance and what meaning are conveyed in the symbols performed in Lariangi dance. The research used descriptive qualitative method to take information. The writer obsereved the house in Liya village and took some informations from them and interviewed and documented by using recorded and camera. This research also took the datum from some books, articles, internet which associat with the symbols in Lariangi dance in Wakatobi Southeast Sulawesi. The research resulted in the part of symbols in Lariangi danfsstaft from Lariangi dance. The result of the research was consisted in four part. First, the symbols found in dress there are six namely Kombo Monihi, Kombo Meha, Punto/Wuray Nibelo Biru, Laka/Wuray Meha, Kambero, and Lenso/Saputangan symbolyzes sweat rag of King Buton. The second, there are eight symbols and their meaning found in accessories, namely Panto and Pintoru, Hepupu/ Konde, Kamba Konde, Toboy Kamba, Hebindu/Sangi-Sangi, Kalo, Naga, Sekori Keponto Posusu symbolyzes degrees nobility. The third, there are four symbols found in movement of Lariangi dance namely, Hematu kepooli le..le, Pajogi/Nyibing/Ngifi, Nabu/Tau, and Lariangi symbolyzes Lighting. The last is symbols found in song of Lariangi dance there are nine songs namely Mangu-Mangu, Ole-Ole, Doumaraia, Denda Aule, Sailila, Waindi-Indi, Rongande, Jojongana, and Salatu symbolyzes as thankful to Allah SWT.
\end{abstract}

Keywords : Semiotic Analysis, Lariangi Dance, Wakatobi, Southeast Sulawesi

\begin{abstract}
Abstrak
Tujuan penelitian ini adalah untuk mengetahui simbol-simbol simbol ditampilkan dalam tarian Lariangi dan makna apa yang disampaikan dalam simbol-simbol yang ditampilkan dalam tarian Lariangi. Dalam penelitian ini menggunakan metode deskriptif kualitatif untuk mengambil informasi. Penulis mengamati rumah di desa Liya dan mengambil beberapa informasi melalui mewawancarai dan mendokumentasikan dengan menggunakan rekaman dan kamera untuk mendapatkan informasi. Penelitian ini juga mengambil data dari beberapa buku, artikel, internet yang dikaitkan dengan simbol-simbol dalam tari Lariangi di Wakatobi Sulawesi Tenggara. Penelitian ini mengungkapkan simbol dalam tari Lariangi mulai dari pakaian, aksesoris, gerakan tarian dan lagu-lagu tari Lariangi. Hasilnya adalah simbol yang ditampilkan dan makna yang disampaikan dalam tari Laariangi terdiri dari empat bagian. Pertama simbol yang ditemukan dalam pakaian ada enam yaitu Kombo Monihi, Kombo Meha, Punto / Wuray Nibelo Biru, Laka / Wuray Meha, Kambero, dan Lenso / Saputangan melambangkan kain keringat Raja Buton. Yang kedua, ada delapan simbol dan maknanya ditemukan dalam aksesori, yaitu Panto dan Pintoru, Hepupu $/$ Konde, Kamba Konde, Toboy Kamba, Hebindu / Sangi-Sangi, Kalo, Naga, Sekori Keponto Posusu melambangkan derajat bangsawan. Yang ketiga, ada empat simbol yang ditemukan dalam gerakan tari Lariangi yaitu, Hematu kepooli le..le, Pajogi / Nyibing / Ngifi, Nabu / Tau, dan Lariangi melambangkan Pencahayaan. Yang terakhir adalah simbol yang ditemukan dalam lagu tari Lariangi ada sembilan lagu yaitu Mangu-Mangu, Ole-Ole, Doumaraia, Denda Aule, Sailila, Waindi-Indi, Rongande, Jojongana, dan simbol Salatu sebagai ucapan terima kasih kepada Allah SWT.
\end{abstract}

Keywords: : Analisis semiotika, Tari Lariangi, Wakatobi, Sulawesi Selatan 


\section{Introduction}

Indonesia is a country that consists of various tribes, cultures, customs and traditions. All of these are priceless wealth when we see from art, history and religion. If it is examined further, it will contain lesson and image from the tribe and society that has each character.In this report, the writer will explain about art paticularly for traditional dance in Wakatobi. Traditional dance is identity reflection of a territory, movement of traditional dance in general is simple and repeatedly. Movement of that dance stacked appropriate with values that reflected life society itself.

Traditional dance is identity reflection of a territory, movement of traditional dance in general is simple and repeatedly. Movement of that dance stacked appropriate with values that reflected life society itself.

In another meaning, Traditional dance is a form of dance that traces its roots back to early or otherwise important foundations of a culture. Depending on the culture of the dance, traditional dance can be referred to as folk dance or ethnic dance.

Traditional dances are taught both as a form of dance and as a way to keep a part of a specific culture alive in new generations. They are sometimes used in ceremonies or as a ceremonial honor but are more often than not practiced unchoreographed and as a social activity rather than a competitive one. Dances that were used in rituals are usually not considered traditional dance and are instead considered a form of culturally religious dancing.

Dance is effort to create the beauty through movement and rhythm formation in movement unit composition to convey certain message. According to Alma Hawkins (1990) : "Dance is the oldest human expression. Experienced that appeared because social movement is result of human necessary to find and look for the real shape in aesthetic aspect from meeting with life. There are two creative experiences and aesthetic because experience will enrich itself as human. The experienced in helped human become an individual that integrated and feel harmonious with the world, to reach totality feeling".

Lariangi dance is a traditional dance from Wakatobi. Lariangi dance is an entertainment dance for the people in Wakatobi, this dance is usually played by twelve local village teenage girls. This dance is very exotic, especially the costumes. The name of this dance costume dance is the same as the name of Lariangi. This dance is performed while singing. Formerly dances in the show to welcome the royal guest.
As one of the traditional dance in wakatobi, Lariangi dance also have some symbols in movements, costumes, traditional dress, accessories and songs. all of those symbols have deep meaning and moral messages.

The term 'semiotics' is relatively new for many people, and a number of conceptual difficulties continue to attach to its use. As Hodge and Kress currently as cited in Saussure (1974) stated that semiotics has been defined as 'the science of the life of signs in society'. So defined it has a scope which is breath taking in its simplicity and in its comprehensiveness. In its term, everything in a culture can be seen as a form of communication, organized, in ways akin to verbal language, to be understood in terms of a common set of fundamental rules or principles.

Semiotics or semiology is the study of sign, symbols, and the signification. It is the study of how meaning is created not what it is. The word of semiotics purportedly taken from Greece 'semeion'. Sign can be found in everywhere, gesture, traffic lights, flag and so forth. As the definition of semiotics is the study of signs and symbols as elements of communicative behavior, the analysis of systems communication, as language, gesture, or clothing.

Semiotics (also called semiotic studies, not to be confused with the Saussurean tradition called semiology) is the study of meaning-making, the philosophical theory of signs and symbols. This includes the study of signs and sign processes (semiosis), indication, designation, likeness, analogy, metaphor, symbolism, signification, and communication. Its Semiotics is closery related to the field of lingustics, which, for its part, studies the structure and meaning of language more specifically.

In A Theory of Semantics book it is also stated by Eco as cited in (Frank, 1957 : Efron, 1941) that 'Semiotics is studied by psychology, present and recognized in communication among the blind and in proxemic behavior and it is amplified to include clearly codified social behavior such as the kiss, the embrace, the smack, the slap on the shoulder and so forth'.

Peirce (1839) proposed a different theory. Unlike Saussure who approached the conceptual question from a study of linguistics and phonology, Peirce was a somewhat kantian philosopher who distinguished 
"sign" from "word" as only a particular kind of sign, and characterized the sign as the means to understanding. The setting of peirce's study of signs is philosophical logic, which he defined as formal semiotic, and characterized as a normative field following esthetics and ethics, as more basic than methaphysics, and as the art of devising methods of research. The result ia a theory not of language in particular but rather of the production of meaning, and it rejects the idea of a static relationship between a sign and that which it represents, its object. Peirce believed that signs are meaningful through recursive relationships that arise in sets of three.

Semiotics of culture is a research field within semiotics that attempts to define culture from semiotic perspective and as a type of human symbolic activity, creation of signs and a way of giving meaning to everything around. Therefore here culture is understood as a system of symbols or meaningful signs. Because the main sign system is the linguistic system, the field is usually referred to as semiotics of culture and language.

Semiotics can be applied to anything which can be seen as signifying something, in other word, to everything which has meaning within a culture. Even within the context of the mass media we can apply semiotic analysis to any median text such as television and films, cartoons, newspaper, magazines articles, posters and so forth.

Culture (Latin: cultura, lit. "cultivation" ) is a modern concept based on a term first used in classical antiquity by the Roman orator Cicero: "cultura animi" (cultivation of the soul). This nonagricultural use of the term "culture" reappeared in modern Europe in the 17th century referring to the betterment or refinement of individuals, especially through education. During the 18th and 19th century it came to refer more frequently to the common reference points of whole peoples, and discussion of the term was often connected to national aspirations or ideals. Some scientists such as Edward Tylor used the term "culture" to refer to a universal human capacity.

Culture is part of us, it was he who guided our values, beliefs, behaviors, and our interactions with others. According to Edward Burnett Tylor, a British anthropolo- gist professor, gives a clear definition of "culture" for the western scientists. Tylor says, "culture as a complex collection of knowledge, belief, art, law, morals, customs and any other capabilities or habits acquired by man as a member of society", although previously, Tylor himself has said that the use of the term culture is very confusing and contradictory. It is also mentioned by Alo as cited in Kroeber and Kluckhohn (1952) that, the term culture can be used to explain how to live a collective society, or explain "culture" as a man who would totality. He also provide modern technical definition of "culture as patterns of thought and behavior that are already known by the public".

Culture is also considered a positive response to the situation and the conditions experienced and going around humans. Positive things as that responter arising from the concept of the symbol in this case recocnized in human social life as a human language that connects between one another in carrying out essentially as social beings in form a group. Clifford Geertz says that culture is the system of inherited conceptions in symbolic form, which in this way people can communicate, preserve, and develop knowledge and attitude towards life. It is explained by Rukaya as cited in Abdullah (2006).

Culture is a word for people's 'way of life', meaning the way groups do things. Different groups of people may have different cultures. A culture is passed on to the next generation by learning, whereas genetics are passed on by heredity. Culture is seen in people's writing, religion, music, clothes, cooking, and in what they do.

Wakatobi island was famous with the name of Tukang Besi island (Artisan Iron Islands). Artisan Iron Islands are an archipelago located on the east side of the Buton island. It was said that due of the population in that archipelago since time immemorial have developed their ability as "Artisan Iron", then the search results based on a long history that is spoken by La Ode Bosa (Historian Buton) estimation as it is, is not true. True, Artisan Iron immortalized as the name of the islands is originated from the events of the presence of several hundred figures Maluku people under the leadership of King Hitu (Ambon island) called "Tuluka Besi".

The king Tuluka Besi with his followers arrived at the Patuno beach (Patahuano) in Wangi - Wangi island as a 
prisoner of VOC. They were removed out of the Moluccas since uprising against VOC that destroy the tree of spices (nutmeg and clove) belonging to the king and the people of Maluku by the Dutch (VOC) destruction of tree movement spice known as Hongi Tochen, since his arrival in Wangi - Wangi island the prisoners revolted again even kill out all VOC soldiers guarding them, then the prisoners devided to several islands separated from each other that region. Besides still in Wangi-Wangi island, partly in Tomia and Binongko.

Dispersal of action of the prisoners from Moluccas to several island in cluster of that archipelago, the population of the kingdom of Buton apparatus, called the cluster of that islands became Tukang Besi island. Tukang Besi

is immortalized as "Artisan Iron". The mention of Artisan Iron for the cluster of that islands occurred since the mid 17th century.

One important thing that might be considered also is a entertaining story about Lariangi dance created and the meaning of symbols told by several respondent when the researcher did the research in Wakatobi.

At the time the Buton kingdom, when the King Wakaaka crowned as the first king (mid XIV century), Lariangi Dance was introduced as a dance palace completion. That is, this dance is only offered to the king to eliminate fatigue.

In 1674, Kasawari commanded the King Buton to teach Lariangi dance to the public, so there is a saying, that "Tekahedupa Tenirabu Teandi-Andi $\mathrm{Nu}$ Wolio," That is, Kaledupa should be fostered as well as assistance from the government the king of Buton in all kinds of fields anything, because at the moment Kaledupa was the second from Buton Kingdom mainland.

Hj Wa Ode Zaramu (La Ode Cio grandchildren, former commander of Kaledupa) said, Lariangi Dance is a dance that contains special meaning, ranging from clothing, singing and movement. Lariangi dance is a dance form of entertainment for the people, the dance is usually played by teenage girls of twelve local villages. Each village has a different version of both the movement and the song. This is caused by differences in Lariangi dance teacher. This dance is very exotic, especially the cos- tumes. The name of this dance costumes together with the name of the dance is Lariangi. Lariangi consists of two syllables. Run and Angi. Running means to decorate or carve. Angi means people decorated with various ornaments to convey information, with a view to provide advice.

Formerly, Lariangi played in the royal palace that serves as an advisor to remember all the movements and nyanyianya unbiased advice as well as the problems of life. Therefore, Lariangi embodied in the movement and singing. They sing in a language of ancient Kaledupa. Currently, this language is not used in everyday conversation. Lariangi dance climax is at the end of the dance is movement called the ngifi. Ngifi is performed by two male dancers. They danced around two female dancers. It contains intentions, the men, under any circumstances must still protect the women.

Another opinion about Lariangi dance is the dance formerly used for war strategy and Supervision Region. Dance concentration is at Liya Fort and Barata Kaledupa. Lariangi of Kaledupa the dancers equipped with pearl shell (now replaced with a mirror) is placed as a crown dancer, intended to reflect light as a code to determine the movement of the enemy or guests who will be present and anchored on the mainland. Reflected light is usually done in a circular motion with a matter of a few times the only known and understood by the guards / commanders of each region in order to be ready. Slightly different from the Lariangi Liya or Lariangi Togonto.

The dancing is synonymous with softness and smoothness graceful the dancers in the picture of Lenso (handkerchief) of young girls depicted in the lyrics of the songs sung. This dance is dedicated to the king / sultan who visited the palace Liya along with other nobles. Now Lariangi dance exhibited in order ceremonial occasions, welcomed the arrival of the old community living overseas or outside the area that needs to be honored. The important thing is the reader should know that Lariangi dance first come from Kaledupa.

Lariangi dance is a dance form of Wakatobi commonly played by twelve young dancers. This exotic dance beside the graceful movements of the dancers, can also be enjoyed from striking yet beautiful costumes worn by the dancers. The twelve dancers in costume Lariangi dance of the same name that this Lariangi, 
besides gestures are also accompanied by songs and sung by the dancers. Twelve pretty young girl, beautiful costumed dancing and singing to the music of joy and sometimes bend sharply and so carefree who is not fascinated watching it.

Forward movements, turned to the left and to the right with the eyes following the end of the swing fan, reflecting an irregular rhythm of motion and also shows that progress is something wonderful. Blend character, costumes and dance movements in Lariangi, there Kinema that women in dress Wakatobi always polite, gentle in action and speak hello, open in dealings with any one, and is consistent in many ways. Lariangi dance it's not seldom showed as entertainment treat guests with officials (state officials) who visited Wakatobi.

In another explanation, Lariangi dance is an entertainment dance for the people in Wakatobi, this dance is usually played by twelve local village teenage girls. This dance is very exotic, especially the costumes. The name of this dance costume dance is the same as the name of Lariangi. This dance is performed while singing. Formerly dances in the show to welcome the royal guest.

Formerly, Lariangi played at the royal palace that serves as lighting. Therefore, Lariangi embodied in the movement and singing. They sing in a language of ancient Kaledupa. Currently, this language is not used in everyday conversation. Lariangi consists of two syllables namely Lari and Angi.

Lari means to decorate or carve. Angi means those decorated with various ornaments to convey information, with the intention to provide advice. It could also be entertainment with dance moves and singing. As the embodiment of the dancers clothing Lari is composed of fabrics, beads, embellishments bun, engraved metal for bracelets, necklaces, and ornate gloves. For example, ornate bun called a monitor like a radar or elaborate hair ornaments once made. Only certain people can make the hair ornaments. Angi is realized in the form of movement and singing. The duration of this dance are ten minutes. For ten minutes, we will see ten beautiful women dancing and singing. The dance is dominated by a circular motion with a flick sit down and Lenso or fan. The climax is at the end of the dance. That movement, called the Nyibing.

Nyibing performed by two male dancers. They danced around the two female dancers. It says something, the men, in any condition must still protect women.

Although at this point, is not merely the Lariangi dance showed in certain events, in the early development of this dance is devoted to greet the royal guests who visit there and only played in the royal palace. Besides, also, this dance was in ancient times often staged for and as a means of illumination. Perhaps because it was also, this dance is played with motion and singing, and also call Lariangi dance, which consists of two words namely Lari has meaningful decorate or carve, and Angi which means people who decorated with some ornaments to convey information, with intention to provide advice. Lari is the embodiment of the word can be seen from the costumes worn by the dancers which consists of fabric, beautiful carved metal circular as bracelets, necklaces and other decorations. Lari can also be seen from the bun is so beautiful ornate and complex called the monitor. That said, to be able to make this monitor decoration is not just anyone can do it. Only certain people and has forged with experience managing monitor the hairpieces that can make this as for the word itself can be reflected Angi motion and singing performed by the dancers. On the dance lasted about ten minutes of this, the movement of the dancers dominated by sitting and circular motion, waving a fan or Lenso with relentless mouth sing. And then on towards the end of the dance, as the culmination of the dance scene this is a smart move called Nyibing.

In this Nyibing dancers performed by two young men walking around the two female dancers in the middle, like a young man who was trying to protect his partner from the dangers that come from the outside. And indeed, rolling dance circles beside two female dancer is said to have a philosophical meaning that a man must be able and willing to protect women from any circumstances and in any case, even if it has to sacrifice their own lives are at stake, because in the eyes of the Wakatobi, women especially partner is honored with a fixed price that must be maintained and protected. Failed to protect her partner is tantamount to fail in life and must bear the shame for life in the body.

\section{Method}

This research will use descriptive qualitative method, which meant that it described and elaborated the facts and the de- 
tailed information sistematicaly in the field of the research. The are two variables that will be assessed In this research: symbols are performed in Lariangi dance and meaning are convey in symbols performed in Lariangi dance. The indicators of symbols performed in dance and meaning of symbols performed in Lariangi dance. The sample of this research used ten (10) experienced people who could introduced and explained how to perpetuate the target of what symbol performed and meanings conveyed in the symbol performed in Lariangi dance.

This method is used to direct explore or material research to obtain the object and analyzed. Analysis in this study will focus on symbols perfomed in Lariangi dance and meanings are conveyed in the symbol meaning of Lariangi dance in Wakatobi. Semiotics method essentially qualitative interpretative a method that focuses itself on the sign and context as object of study, as well as how researchers interpret and understand code behind symbols and meaning.

\section{Finding and Discussion}

According to most of the respondent, besides for the king, Lariangi dance also is used for entertaining, expression of gratitude to god, welcoming the arrival, ceremonial occasions, wedding ceremony, and overseas. The dancers will called by the host if there is ceremony like that. Before the dancer showed on stage, the teacher of Lariangi dance will call the dancers to train in teacher place. Means to prepare their self around one week before showed started from dress, accessories, songs and movement of dance. They are really pay attention about that.

To make the readers easier to understand well about the symbols performed in Lariangi dance and their meaning, the writer in this working paper would like to discuss shortly about the following items. The items will be explained as follows:

\section{The Symbols Found in Dress}

In Lariangi dance, there is one dress but have four layers dress. The people in Wakatobi regency call them Kombo Monihi (Thin Kombo/Shirt), Kombo Meha (Red Kombo), Punto/Wuray Nibelo Biru (Black Gloves), Laka/Wuray Meha (Red Gloves) and two equipment namely Kambero (Fan) and Lenso/Sapu Tangan (Handkerchief).

- Kombo Monihi (thin kombo) is a shirt designed especially for Lariangi dance and to wear at part out.

- Kombo Meha (red kombo), Punto/ Wuray Nibelo Biru (black gloves), Laka/Wuray Meha (red gloves), is designed as the layer and worn first in the body before Kombo Monihi.

- Kambero (fan) and Lenso/Sapu Tangan (handkerchief) is used to make the movement in Lariangi dance more beautiful beside that fan and handkerchief for the King.

\section{The Symbols Found in Accessories}

In this part, the accessories is used to make the dancer good looking and also because the accessories have good meaning. The accessories in functions and meaning as follows:

- Panto and Pintoru (Crown) is used on the head and Total panto usually there are three pieces which are attached in a bun (representing the degree of nobility).

- Hepupu/Konde (Bun) is a part of crown symbolizes Buton kingdom.

- Kamba Konde ( Flower Bun) is an accessories like flower that used on the bun.

- Toboy Kamba (Flower) is an accessories that stay on the bottom Kamba or flower.

- Hebindu/Sangi-Sangi (Hair Decoration) is a decoration of hair. The shape of Hebindu is used for marriage event, Kariya and Lariangi.

- Kalo (Necklace) is the special necklace just used in Lariangi dance or Kariya event. Naga (Dragon) symbolizes the fortress palace guard. The composition of the necklace of the above, namely: Loma (butterfly), Jaojaonga and naga.

- Sekori Ke Ponto Posusu (Stackable Bracelet) symbolizes the degree of nobility. Number of rings there are four in each hand and sekori only numbered 1 and placed on the left arm.

3. The Symbols Found in Movement of 


\section{Lariangi Dance}

In this stage, there are some movement of Lariangi dance that will be explained as follows:

- Hematu ke Pooli le... (Opening and Closing) is a movement that done when the dance opening and closing by saying Le....

- Pajogi/Nyibing/ Ngifi (Dance) is a dance that performed in climax of dance. Ngifi is the last part of Lariangi dance two girls will dance while singing on the stage and two male surrounded them.

- Nabu/Tau (Souvenir) is two dancers perform dances in the middle alternately and then people give enough money or souvenirs in chamfer sometimes two boys or two Nyibing came to middle and dance together with the girls after that the boys will take the handkerchief of dancer then the boys go out to give some money to handkerchief then they back to middle and give back her handkerchief with money. The people who called the dancer also will give anything souvenir it means to honor them.

- Lariangi (decorate and decorated) is the name of dance and also all the movement and dress called Lariangi.

4. The Symbols Found in Songs of Lariangi Dance

There are many songs that brought in Lariangi dance. In the past time when Lariangi dance showed in the kingdom until the dance spread the songs are fourteen and usually the dance performed when the evening until morning come. But now, the dancer sometimes just brought five until six song depend on the dancer. This bellow is a song of Lariangi dance by using Kaledupa language (song of the full advice and praise to the creator and king):

Iamalahu

Iamalahu aulah rah

Buna iamalahu ura

Can aidina lasulutanu

Lambikulia he saihuna abuduluka

Etapene ilabana bente

Etapene ilabana bente

Ladaengkarae ...... . betakamata

E ... ..kapala simpomoo omba

E... ..kapala simpomoo omba

Ladaengkarae ... ..musula mea
E ... ..tombi-tombi na folio

E ... ..tombi-tombi na folio

Ladaengkarae ... musulaia

E ... .polisi na Baubau

E ... .polisi na Baubau

Ladaengkarae ...... .le ... e ... le ......

The type and meaning in the song of Lariangi dance, Namely:

- Mangu-Mangu (anthem), Tanaka (songs mandatory), Ialamahu (anthem), are the song that sang in the opening dance. This song always brought everytimes of Lariangi dance performed. These songs are the first songs that must be brought and the dancer can choose which song they want.

- Sailila (romance), Waindi-indi (Love), Ritanjo (romance), Ayonda (Love), Mammary (romance) are the songs that contain a certain thing about love as the consoler song for the audience. These songs brought after the anthem song and the dancer will take one or two songs that dancer want about love.

- Doumaraia (advice) is the song that sometimes brought by the dancer to the audience in every ceremony.

- Rongande (false Promise) is a song that brought when the dance performed in a big ceremony like quest reception. This song usually contain about promises of government and also a false promise from someone who ever promised to us but never fulfill a promise.

- Denda Aule (for the nomads) is the song that used for the nomads means this song just brought when the householder asked the dancer to showed Lariangi dance for the nomads.

- Jojongana (Advice life) is a song that also always brought to entertain the audience that contain about advice in running this life.

- Ole-Ole is the song that should brought by the dancer because it's the special and the main thing of dance. Ole-Ole is created by the teacher of dance for every ceremony and directed for the host.

- Salatu is a song that talking about an expression of gratitude to the creator. This song created by the teacher of Lariangi dance as thankfulness to god. 


\section{Conclusion}

After reading and understanding the symbols performed in Lariangi dance and their meaning, the writer of this working paper would like to draw conclusions as follows:

1. There are four parts of symbols that are found in Lariangi dance namely, the symbols found in dress: Kombo Monihi, Kombo Meha, Punto/Wuray Nibelo Biru, Laka/Wuray Meha, Kambero, and Lenso/Saputangan. The symbols found in accessories: Panto and Pintoru, Hepupu/Konde, Kamba Konde, Toboy Kamba, Hebindu/Sangi-Sangi, Kalo, Naga, Sekori Keponto Posusu. The symbols found in movement of Lariangi dance: Hematu kepooli le..le.., Pajogi/Nyibing/ Ngifi, Nabu/Tau, and Lariangi. The last is symbols found in song of Lariangi dance: Mangu-Mangu, Ole-Ole, Doumaraia, Denda Aule, Sailila, Waindi-Indi, Rongande,Jojongana, and Salatu.

2. Every symbol above has meanings and the meanings of symbols are found in dress, in accessories, in movement of Lariangi dance, and in song. Some of meaning of symbols in dress are a beautiful women who has been married and Queen Wa Kaa - Kaa, one of meaning in accessories is nobility degree, a meaning of symbol in movement of dance is respect for the dancers, and one of song has meaning as thankful to Allah SWT.

3. So, the symbols performed in Lariangi dance and their meanings are found in four part. First the symbols found in dress there are six namely Kombo Monihi, Kombo Meha, Punto/Wuray Nibelo Biru, Laka/Wuray Meha, Kambero, and Lenso/Saputangan symbolyzes sweat rag of King Buton. The second, there are eight symbols and their meaning found in accessories, namely Panto and Pintoru, Hepupu/Konde, Kamba Konde, Toboy Kamba, Hebindu/SangiSangi, Kalo, Naga, Sekori Keponto Posusu symbolyzes degrees nobility. The third, there are four symbols found in movement of Lariangi dance namely, Hematu kepooli le..le, Pajogi/Nyibing/ Ngifi, Nabu/Tau, and Lariangi symbolyzes Lighting. The last is symbols found in song of Lariangi dance there are nine songs namely Mangu-Mangu, Ole-Ole, Doumaraia, Denda Aule, Sailila, Waindi-Indi, Rongande, Jojongana, and Salatu symbolyzes as thankful to Allah SWT.

\section{References}

Hawkins Alma. 1990. An Educator in Dance is Dead94.http:// www.nytimes.com/1990/01/24/arts/ alma-hawkins-an-educator-in-dance-is -dead-at-94.html. (accessed on 11stJanuary, 2014)

http://baltyra.com/2009/10/11/tari-lariangi/, Accessed on $20^{\text {th }}$ Maret 2015.

Hodge and Kress. 1974. Currently as cited in Saussure. New York : Hastings.

Ayto. 1990. Dictionary Of Word Origins. The Hiistory Of More than 8000 English. Language Words.

Frank. 1957. A Theory of Semantics. New York : Cambridge University.

Crystal, David. 1985. What Is Informal language. Retrieved from http:// www.sil.org/LINGUISTIC/ GlossaryOfLinguisticTerms/ WhatisInformalLanguage.htm. Access date:02/09/2014

Kroeber and Kluckhohn. 1952. Culture : A Critical. Review Of Concepts and Definition. New York : Vintage. 